\title{
GENETICS AND EXPECTED SELECTION GAIN FOR GROWTH TRAITS IN EUGENIA DYSENTERICA DC. POPULATIONS ( $\left.{ }^{1}\right)$
}

\author{
ANANDA VIRGINIA DE AGUIAR $\left(\left(^{*}\right)\right.$; ROLAND VENCOVSKY $\left({ }^{3}\right)$; LÁZARO JOSÉ CHAVES $\left({ }^{4}\right)$; \\ MARA FERNANDES MOURA $\left({ }^{5}\right)$; LIZZ KEZZY DE MORAIS $\left({ }^{6}\right)$
}

\begin{abstract}
The objective of this study was to estimate genetic parameters of quantitative traits in a living germplasm collection of Eugenia dysenterica. The genetic material consisted of 110 progenies derived from 10 natural Eugenia dysenterica subpopulations sampled in the southeastern region of the state of Goiás. The experiment was established in a complete randomized block design, with 110 treatments, four replications and one tree per plot. The study variables were total height, stem diameter and respective growth rates. After the analysis of variance some genetic parameters were estimated. The levels of genetic variation in the collection were high and the highest proportion was found within subpopulations. Highest coefficients of heritability and genetic variation were observed in subpopulations from the counties Catalão, Três Ranchos, Cristalina and Senador Canedo. Considering the promising expected progress for growth traits, this collection can be converted into an unrogued seedling seed orchard, aiming the production of improved seed.
\end{abstract}

Key words: Eugenia dysenterica, pre-breeding or screening, genetic conservation, Cerrado, genetic parameters, heritability.

\section{RESUMO}

\section{GENÉTICA E PROGRESSO ESPERADO NA SELEÇÃO DE CARACTERES DE CRESCIMENTO EM POPULAÇÕES DE CAGAITEIRA}

O objetivo deste trabalho foi estimar parâmetros genéticos de caracteres quantitativos da coleção de germoplasma in vivo de Eugenia dysenterica. O material de estudo foi composto por 110 progênies de dez subpopulações naturais de cagaiteira amostradas na Região Sudeste do Estado de Goiás. O delineamento experimental adotado foi de blocos completos casualizados, com 110 tratamentos, quatro repetições e uma árvore por parcela. As variáveis avaliadas foram altura total, diâmetro do fuste e respectivas taxas de crescimento. Após a análise de variância foram estimados parâmetros genéticos populacionais. As subpopulações naturais de cagaiteira tiveram altos níveis de variação genética e a maior proporção foi verificada dentro de subpopulações. Os maiores coeficientes de herdabilidade e de variação genética ocorreram nas subpopulações dos municípios de Catalão, Três Ranchos, Cristalina e Senador Canedo. Considerando os bons progressos esperados para caracteres de crescimento, essa coleção pode ser convertida em um pomar de sementes por mudas, sem desbaste, visando à produção de sementes melhoradas.

Palavras-chaves: cagaiteira, pré-melhoramento, conservação genética, Cerrado, parâmetros genéticos, herdabilidade.

( $\left.{ }^{1}\right)$ Receipt for publication in September 10, 2008 and accepted in April 3, 2009.

(2) Embrapa Florestas, Estrada da Ribeira, km 111, 83411-000 Colombo (PR). E-mail: ananda@ cnpf.embrapa.br (*) Corresponding author.

$\left({ }^{3}\right)$ Escola Superior de Agricultura Luiz de Queiroz (ESALQ-USP), Departamento de Genética, 13428-900 Piracicaba (SP). E-mail: rvencovsky@esalq.usp.br

$\left({ }^{4}\right)$ Universidade Federal de Goiás, Departamento de Genética e Melhoramento de Plantas e Engenharia de Alimentos, Goiânia (GO).

${ }^{5}$ ) Instituto Agronômico (IAC), Centro de Fruticultura, Av. Luiz Pereira dos Santos, 1500, Bairro Corrupira, 13020-902 Jundiaí (SP).

$\left({ }^{6}\right)$ Instituto Agronômico (IAC), Centro de Grãos e Fibras. Av. Barão de Itapura, 1481, 13020-902 Campinas (SP). 


\section{INTRODUCTION}

Some native Cerrado fruit trees are promising for domestication. Most of them are used by the local population, though there is little or no commercial cultivation. Consequently, the exploration of these fruits by extractivism is often predatory. The chances of genetic erosion or drift of such species are high due to the advance of agriculture and animal husbandry in the Cerrado, besides other forms of human actions. In this situation, knowledge on the existing genetic variability in natural populations of fruit tree species could contribute to an adequate management of the reminiscent ecosystems and for the development of better adapted varieties for cultivation in the consumption regions.

The cagaita tree (Eugenia dysenterica DC.) is one of the auspicious fruit tree species of the Cerrado, particularly considering its processed products. The species is being studied at the Universidade Federal de Goiás, since 1995 for the characterization of the genetic variability, propagation, genetic conservation and domestication.

Eugenia dysenterica has a "big bang" flowering strategy, where flowering occurs on the large scale and synchronized in a very short time (PROENÇA and GIBBS, 1994). The hermaphrodite flowers are white, large and grow separately (CORREA 1984). The mixed reproductive system of the species tends to allogamy, with a cross pollination rate between $84 \%$ and $100 \%$ (Telles et al., 2003 and Zucchi et al., 2003).

The natural populations of the species in the state of Goiás, namely in the southeastern and northeastern regions of the state, are being studied aiming at the conservation of the genetic variability. Most studies focused on the characterization of variability levels (percentage of polymorphic loci, number of alleles per locus and mean heterozigosity), the distribution of the molecular and quantitative variability among and within populations, the determination of the reproductive system and of the micro-evolutive procedures that occur in the populations (TelLes et al., 2001a, b; ZuCCHI et al., 2003; Telles et al., 2003; ZuCCHI , 2005; TRINDADE and Chaves, 2005). Since researches with Eugenia dysenterica are recent, the study of genetic improvement is still in the early stages. But the information obtained so far is fundamental for the definition of in situ, on farm and ex situ conservation strategies, and as orientation of selection programs.

On this background, the study objective was to estimate genetic parameters of growth traits in trees of the living E. dysenterica germplasm collection of the Escola de Agronomia e Engenharia de Alimentos of the Universidade Federal de Goiás. We expect to contribute to conservation and improvement programs targeting the species' incorporation into regional production systems.

\section{MATERIAL AND METHODS}

The trees evaluated in this study are part of a germplasm collection, planted at the Escola de Agronomia e Engenharia de Alimentos of the Universidade Federal de Goiás. The seeds were collected in regions of natural occurrence of the species, in October 1996. Fruits of cagaita trees were sampled in ten subpopulations from eight to twelve plants per subpopulation, in the southeastern region of the state of Goiás (collection sites specified in Table 1 and Figure 1).

The seeds were sown in an experimental nursery and evaluated in the early development phase (SILVA, 1999). In January 1998, four plants of each family were transplanted to the field, in an experimental design of complete randomized blocks, with 110 treatments (families), four replications and one plant per plot, in a $6 \mathrm{~m} \times 6 \mathrm{~m}$ spacing, totalizing 440 plants. In the first year, dead or unhealthy plants were replaced with remnant plants. The mean number of families per subpopulation varied from eight to twelve, with an average of 11 plants (Table 1). The original vegetation of the experimental area was a semideciduous forest and the soil classified as a Dark red Latosol. The area had previously been used as pasture.

\section{Analysis of variance and estimates of genetic parameters}

In the first four years after sowing data of plant height $(\mathrm{H})$ and stem diameter $30 \mathrm{~cm}$ from the ground (D) were recorded every year. Growth rates for height $(\mathrm{bH})$ and diameter $(\mathrm{bD})$ were calculated, estimating a linear regression coefficient for each plant over years, resulting in a total of ten variables.

The data were submitted to an analysis of variance the treatments source of variation being subdivided into components due to subpopulations and families within subpopulations. Based on these estimates the proportions of genetic variation among subpopulations $\left(\mathrm{P}_{\mathrm{A}}\right)$ and within subpopulations $\left(\mathrm{P}_{\mathrm{W}}\right)$, the heritability coefficients among family means $\left(\mathrm{h}_{\mathrm{m}}^{2}\right)$, individual $\left(\mathrm{h}_{\mathrm{i}}{ }_{\mathrm{i}}\right)$ and on a plant basis within families $\left(\mathrm{h}^{2}{ }_{\mathrm{w}}\right)$ were obtained. Furthermore the expected selection gain among $\left(\triangle G_{A}\right)$ and within $\left(\triangle G_{w}\right)$ families was estimated, according to RESENDE et al. (1995). Expressions were multiplied by $(1+s) / 2$ since 
collection was admitted on one sex only, parameters $s$ being the natural selfing rate of the species. For this purpose, the genetic variation among all families was considered, disregarding populations. To compute the expected progress among and within families, ignoring subpopulations, a selection intensity of $20 \%$ among and $25 \%$ within families was assumed. The total expected progress from selection $\left(\triangle G_{T}\right)$ was calculated considering the sum of gains among and within subpopulations.

For calculating the expected progress selection was admitted only on female gametes (VENCOVSKY et al., 2001). In this selection procedure, seeds are collected from the best plants of the best families, with subsequent open pollination and without thinning of any tree. It is therefore admitted that pollen can come from any plant of the group. In the calculations the natural selfing coefficient of the species estimated by Zucchi (2002) and Telles (2000), s=0.08 was considered (mean value of the estimates obtained by these authors).

To evaluate the quantitative variation of each variable, estimates of the $\mathrm{h}_{\mathrm{m}}{ }_{\mathrm{m}}$ coefficient and of the coefficient of genetic variation $\left(\mathrm{CV}_{\mathrm{g}}\right)$ were also obtained for each subpopulation.

For total height and plant diameter, these estimates were calculated for each age, for evaluating the tendencies of these indicator values of quantitative variation of the traits throughout the growth period and for improving their reliability.

Table 1. Sampled sites, geographic coordinates and number of sampled cagaita trees, in the southeastern region of Goiás

\begin{tabular}{|c|c|c|c|c|c|}
\hline Subpopulations & Site (county) & Seed trees & Altitude & Latitude & Longitude \\
\hline & & n. ${ }^{\circ}$ & $\mathrm{m}$ & & \\
\hline 1 & Catalão & 11 & 880 & $18^{\circ} 07^{\prime} 35^{\prime \prime} \mathrm{S}$ & $47^{\circ} 54^{\prime} 20^{\prime \prime} \mathrm{W}$ \\
\hline 2 & Catalão & 11 & 860 & $18^{\circ} 02^{\prime} 03^{\prime \prime} \mathrm{S}$ & $48^{\circ} 02^{\prime} 31^{\prime \prime} \mathrm{W}$ \\
\hline 3 & Catalão & 12 & 800 & $18^{\circ} 13^{\prime} 39^{\prime \prime} \mathrm{S}$ & $47^{\circ} 58^{\prime} 12^{\prime \prime} \mathrm{W}$ \\
\hline 4 & Três Ranchos & 12 & 820 & $18^{\circ} 17^{\prime} 15^{\prime \prime} \mathrm{S}$ & $47^{\circ} 48^{\prime} 41^{\prime \prime} \mathrm{W}$ \\
\hline 5 & Campo Alegre of Goiás & 12 & 930 & $17^{\circ} 39^{\prime} 11^{\prime \prime S}$ & $47^{\circ} 46^{\prime} 37^{\prime \prime} \mathrm{W}$ \\
\hline 6 & Campo Alegre of Goiás & 12 & 780 & $17^{\circ} 34^{\prime} 24^{\prime \prime} \mathrm{S}$ & $47^{\circ} 42^{\prime} 12^{\prime \prime} \mathrm{W}$ \\
\hline 7 & Cristalina & 8 & 890 & $17^{\circ} 10^{\prime} 47^{\prime \prime S}$ & $47^{\circ} 31^{\prime} 07^{\prime \prime} \mathrm{W}$ \\
\hline 8 & Luziânia & 12 & 900 & $16^{\circ} 28^{\prime} 48^{\prime \prime} \mathrm{S}$ & $47^{\circ} 48^{\prime} 40^{\prime \prime} \mathrm{W}$ \\
\hline 9 & Goiânia & 8 & 740 & $16^{\circ} 40^{\prime} 30^{\prime \prime} \mathrm{S}$ & $49^{\circ} 14^{\prime} 42^{\prime \prime} \mathrm{W}$ \\
\hline 10 & Senador Canedo & 12 & 840 & $16^{\circ} 37^{\prime} 13^{\prime \prime} \mathrm{S}$ & $49^{\circ} 04^{\prime} 29^{\prime \prime} \mathrm{W}$ \\
\hline
\end{tabular}

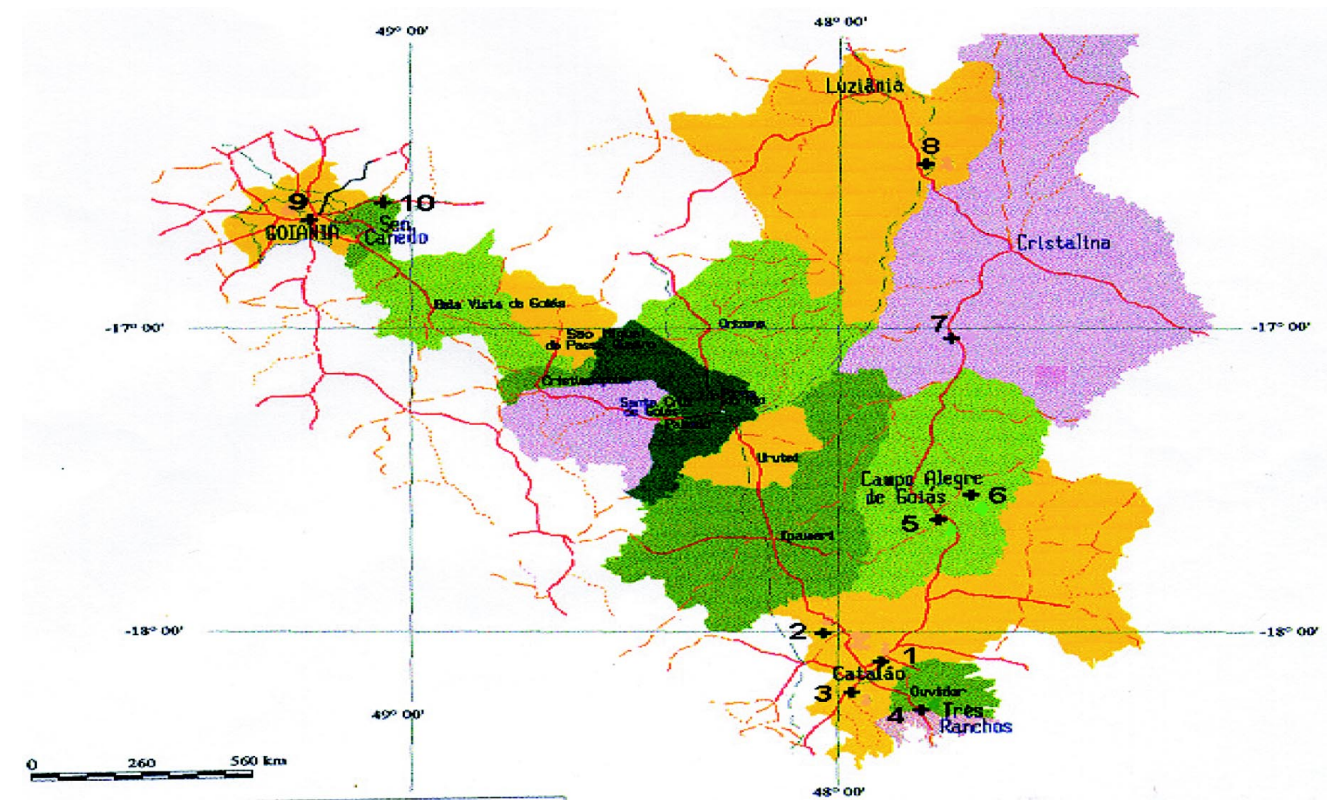

Figure 1. Counties and location of the sampling areas of E. dysenterica DC. in the southeastern region of the state of Goiás (Zucchi, 2002). 


\section{RESULTS AND DISCUSSION}

\section{Survival, growth and genetic variation}

Of the 440 plants in the first year, 381 survived until the fourth year, which represents a loss of $13 \%$ of all plants of the collection. This loss can be considered low since few studies on the propagation technique are available for this species. It can be said that the current Eugenia dysenterica germplasm collection is still representative of the initial material of the existing natural subpopulations in the collection. It is worth remembering that although only four plants per progeny were used, this number can be considered adequate for the research objectives, owing to the wide genetic variation expected in these populations, and considering that the experimental area will be converted into a seed orchard in the future.

The results of the analysis of variance of plant height and diameter of the four first years after sowing and of the growth rate in height and diameter are shown in Table 2 . The coefficients of variation due to experimental errors $\left(\mathrm{CV}_{\text {exp }}\right)$ varied from $31.9 \%$ to $45.7 \%$. These are relatively high when compared with similar experiments for domesticated tree species and with a higher number of plants per plot. These values are probably result of the small plot size along with the high inherent variation of the experimental material. Lower values were found by Silva (1999) who evaluated the same traits in the same families in a greenhouse, using around 15 plants per plot.

The mean values $(\bar{X})$ for both traits confirmed the relatively slow development of cagaita trees. Four years after transplanting the mean tree height had reached about $1.68 \mathrm{~m}$ and a diameter of 3.66 $\mathrm{cm}$. This tendency can be verified as well in the annual increments in height $(\mathrm{bH})$ and diameter $(\mathrm{bD})$ of about $0.38 \mathrm{~m}$ and $0.88 \mathrm{~cm}$, respectively. Nevertheless, in spite of the slow growth, some plants began flowering in the fourth year. SiLvA (1999) also found a slow development of cagaita trees in a nursery with the same families of the same subpopulations used here. TRINDADE (2001) believes this is a common performance of Cerrado species, where the growth of the root system is often greater than of the aerial part. According to the author, this behavior is a natural response to the establishment of the plants in these regions, which have very welladapted mechanisms to the environmental conditions (long dry period), with fast root growth and development of reserve organs.

Table 2. Results of the analysis of variance, percentage of the variability among $\left(\mathrm{P}_{\mathrm{A}}\right)$ and within subpopulations ( $\left.\mathrm{P}_{\mathrm{W}}\right)$, coefficients of heritability among $\left(\mathrm{h}^{2}{ }_{\mathrm{m}}\right)$, individual $\left(\mathrm{h}_{\mathrm{i}}^{2}\right)$ and within progenies $\left(\mathrm{h}_{\mathrm{d}}^{2}\right)$, expected gain by selection among $\left(\triangle G_{A}\right)$ and within progenies $\left(\triangle G_{W}\right)$ and total $\triangle G_{T}(\%)$ for the height, diameter and the respective growth rates of 10 cagaita (E. dysenterica) subpopulations of the southeastern region of the state of Goiás, 2004

\begin{tabular}{|c|c|c|c|c|c|c|c|c|c|c|c|}
\hline \multirow{2}{*}{ F.V. } & \multirow[b]{2}{*}{ GL } & \multicolumn{10}{|c|}{ Mean Square } \\
\hline & & $\mathrm{H} 1$ & $\mathrm{H} 2$ & H3 & $\mathrm{H} 4$ & $\mathrm{bH}$ & D1 & D2 & D3 & D4 & $\mathrm{bD}$ \\
\hline Blocks & 3 & 0.226 & 0.627 & 2.664 & 2.922 & 0.181 & 1.241 & 7.756 & 17.202 & 24.700 & 1.463 \\
\hline Subps & 9 & $0.139^{*}$ & 0.198 & 0.405 & 0.439 & 0.025 & $0.729^{*}$ & 1.490 & 1.323 & 1.401 & 0.073 \\
\hline Fams/Subps & 100 & $0.066^{*}$ & $0.162^{* *}$ & $0.452^{* *}$ & $0.536^{* *}$ & $0.041^{* *}$ & $0.352^{* *}$ & $0.963^{* *}$ & $1.990^{* *}$ & $2.153^{* *}$ & $0.137^{*}$ \\
\hline Residual & $\mathrm{n}$ & 0.050 & 0.099 & 0.252 & 0.298 & 0.026 & 0.236 & 0.577 & 1.107 & 1.367 & 0.101 \\
\hline$C V_{\exp }(\%)$ & - & 37.0 & 32.3 & 33.7 & 32.4 & 42.4 & 45.7 & 35.6 & 34.5 & 31.9 & 36.3 \\
\hline Mean $(\bar{X})$ & - & 0.60 & 0.98 & 1.49 & 1.68 & 0.38 & 1.06 & 2.14 & 3.05 & 3.66 & 0.88 \\
\hline $\mathrm{P}_{\mathrm{A}}(\%)$ & - & 30.27 & 5.67 & 0.00 & 0.00 & 0.00 & 23.63 & 11.87 & 0.00 & 0.00 & 0.00 \\
\hline $\mathrm{P}_{\mathrm{W}}(\%)$ & - & 69.73 & 94.33 & 100.00 & 100.00 & 100.00 & 76.36 & 88.12 & 100.00 & 100.00 & 100.00 \\
\hline $\mathrm{h}_{\mathrm{m}}^{2}{ }^{2}$ & - & 0.32 & 0.40 & 0.44 & 0.44 & 0.34 & 0.39 & 0.43 & 0.39 & 0.34 & 0.22 \\
\hline \multirow[t]{2}{*}{$\mathrm{h}_{\mathrm{i}}^{2}$} & - & 0.20 & 0.26 & 0.30 & 0.30 & 0.22 & 0.25 & 0.29 & 0.25 & 0.22 & 0.13 \\
\hline & - & $(0.112)^{3}$ & $(0.128)$ & $(0.136)$ & $(0.136)$ & $(0.116)$ & $(0.126)$ & $(0.134)$ & $(0.126)$ & $(0.116)$ & $(0.090)$ \\
\hline$h^{2}{ }^{2}$ & - & 0.31 & 0.46 & 0.50 & 0.50 & 0.34 & 0.43 & 0.48 & 0.40 & 0.32 & 0.18 \\
\hline$\triangle \mathrm{G}_{\mathrm{A}}(\%)^{2}$ & - & 5.72 & 6.84 & 7.96 & 7.66 & 7.18 & 9.27 & 8.35 & 7.25 & 5.52 & 3.78 \\
\hline$\triangle G_{W}(\%)^{2}$ & - & 6.57 & 8.43 & 9.83 & 9.47 & 8.34 & 11.25 & 10.17 & 8.44 & 6.09 & 3.90 \\
\hline$\triangle \mathrm{G}_{\mathrm{T}}(\%)^{2}$ & - & 12.29 & 15.27 & 17.79 & 17.13 & 15.52 & 20.52 & 18.42 & 15.69 & 11.61 & 7.68 \\
\hline
\end{tabular}

* and ${ }^{* *}$ : $\mathrm{F}$ test significant at $5 \%$ and $1 \%$, respectively. $\mathrm{n}=$ degree of freedom of the residue that ranged from 261 to 271 . 1 - $\mathrm{H}_{1}$ height in the $1^{\text {th }}$ year after planting $(1=1,2,3,4), \mathrm{bH}$ growth rate of the height, $\mathrm{D}_{1}$ Dmeter in the $1^{\text {th }}$ year after planting $(1=1,2,3,4)$, bD growth rate of the diameter, 2- Parameters estimated disregarding effects of subpopulations and 3- error of narrow sense individual heritability. 
For the study variables there were significant differences among families at levels of $1 \%$ and $5 \%$ probability, depending on the trait and year of evaluation (Table 2). This demonstrates the existence of genetic variability for growth and indicates the possibility of selecting fast-growing plants in this collection. There were significant differences for plant height and stem diameter among subpopulations in the first year only, at a level of $5 \%$ probability. This agrees only partly with results obtained by SILVA (1999) where more significance was found for the among subpopulations genetic variance, relative to traits $\mathrm{H}$ and $\mathrm{D}$ of plantlets. The same study showed that the differences of development of plantlets in the initial phase, aside from the contribution of genetic nature, might be influenced by maternal effects, since a correlation between the initial vigor and seed size was detected, which in turn could be influenced by non-genetic factors (climate, nutrition, plant age etc). This correlation tended to shrink with increasing plant age. Genetic variation among maternal families is expected, as it contains approximately $25 \%$ of the additive genetic variance present within subpopulations. Genetic variation among subpopulations, on the other hand, is also expected for this material due to the divergence that exists, caused by local adaptations, drift and reduced or absent gene flow (TRINDADE and CHAVES, 2005).

\section{Components of genetic variance and divergence}

In this study the partitioning of the total variation among families showed that the genetic variability is concentrated within subpopulations (Table 2). Of the total genetic variation, considering all ten variables jointly, only $7.14 \%$ was found among the subpopulations and $92.86 \%$ within them. SILVA (1999) also verified a greater proportion of the variability among families within subpopulations than among the means of subpopulations for height and diameter at 250 days after sowing. Silva et al. (2001) characterized fruits from the same seed parents and also observed significant variation among plants for all fruit traits; the proportion of the variation found among subpopulations was $16.4 \%$ of the total variation. It is worth pointing out that environmental effects are included in the percentage of total variation observed by the author, since the data were obtained from the seed trees in natural conditions, that is, without control of the environmental effect.

The genetic divergence among and within these ten subpopulations was also evaluated using genetic markers (Telles et al., 2003, ZuCCHI et al., 2003, 2005 ). In a study with isozymes (Telles et al., 2003) based on six enzyme systems and total of nine loci, the variation among subpopulations was high $\left(\theta_{\mathrm{p}}\right)=0.154$ and $\left.\mathrm{G}_{\mathrm{ST}}=0.164\right)$. ZuCCHI (2002) used two different molecular markers (RAPD and microsatellites) for the same purpose and also verified considerable genetic divergence among subpopulations but higher than previously found with isozymes. With RAPD, the author observed that $27.03 \%$ of the genetic variability was found among and $72.97 \%$ within subpopulations $\left(\phi_{\mathrm{ST}}=\right.$ 0.2703 ) when only the seed trees had been genotyped. Considering only seedlings of the families the variability among subpopulations was $32.82 \%\left(\phi_{\mathrm{ST}}=0.3282\right)$. ZuCCHI et al., 2003, 2005 also obtained an $\mathrm{F}_{\mathrm{ST}}=0.318$ based on allele frequencies of the seed trees. A divergence of 0.264 was detected by microsatellite loci, based on the parameter $\mathrm{R}_{\mathrm{ST}}$ (ZucCHI et al. 2003, 2005).

The results based on the three molecular markers and on the quantitative traits here investigated did not agree entirely in relation to the percentage of the existing genetic variation among cagaita subpopulations. Nevertheless, these studies agree that the highest percentage of variation is found within subpopulations. Moraes (1992) conducted a similar study in two natural Myracrodruon urundeuva populations based on 14 quantitative traits and three isozyme loci. Results based on markers versus quantitative traits were also congruent, as both indicated more genetic variability within than among populations.

Studies with Cerrado species show a considerable genetic variation among subpopulations (Chaves and Telles, 2006). Trindade et al., (2005) adds that the high genetic variability obtained with molecular markers among cagaita subpopulations from southeastern Goiás is due to more intense fragmentation processes that occur over a longer time period, differently from the northeastern region where the differentiation levels among subpopulations are lower. From the point of view of genetic conservation, fragmentation has very serious consequences when it comes to be a hindrance of the natural processes with metapopulations (TRINDADE 2001). The preservation of few genetic reserves would therefore be insufficient for the conservation of the species. The maintenance of plants along the roadsides (especially in plain, continuous and practically untouched areas) and in the legal reserves of rural properties could therefore be alternative methodologies in the sense of making gene flow possible (connecting fragments), to maintain most part of the variability and, consequently, the metapopulation structure of the species (Chaves and Telles, 2006). 


\section{Heritability and genetic progress}

The heritability coefficient for family means ignoring subpopulations, varied from 0.22 to 0.44 and within progenies from 0.18 to 0.50 , for the ten study variables (Table 2). These coefficients indicate the possibility of gain from selection among as much as within progenies for the considered traits of juvenile vigor, if superior plants of the best families of this germplasm collection were selected. The heritability estimates $\left(\mathrm{h}_{\mathrm{m}}^{2}\right)$ of both traits showed consistency over ages. This increases the reliability of the results, in spite of knowing that there is a natural correlation between these estimates.

With the applied selection intensities, the expected selection gain within families was higher than the expected among progenies for all variables. The $\triangle \mathrm{G}_{\mathrm{A}} \%$ values, disregarding subpopulations, varied from $3.78 \%$ to $9.27 \%$ and the $\triangle \mathrm{G}_{\mathrm{W}} \%$ values in turn varied from $3.90 \%$ to $11.25 \%$. The total gain $\left(\triangle \mathrm{G}_{\mathrm{T}} \%\right)$ among and within families ranged between $7.68 \%$ and $20.52 \%$ (Table 2).

The concentration of genetic variability within these subpopulations indicates that an improvement program for developmental traits should primarily, focus on selection within families, and secondly among families with lower intensity, ignoring subpopulations. For the genetic improvement of perennial species, after selecting the target germplasm, the size of the base population must be defined, which should contain enough genetic variability for improvement in the short as well as in the long term. In this case it is best to start off with a base population represented by a high number of families of several populations to allow for a high selection intensity within families in the earliest generations and, simultaneously, maintaining effective size compatible with long-term breeding (RESENDE, 1999). It is important remembering that the effective subpopulation size is affected mostly by the among families selection.

According with the expected gain from selection calculated for this living E. dysenterica germplasm collection, the best plants thereof can be used as parents of a seed orchard, without rouging. Since expected gains, assuming selection based on one sex only, were considerable it was concluded that setting up clonal seed orchard will also provide good results. Higher gains are expected in this case, since the plants are selected based on both sexes. This would of course require the development of efficient cloning techniques for plants of this species. In our study only developmental traits of juvenile plants were evaluated. It was assumed that trees that develop faster are earlier in yield, a highly important trait in perennial species. The trees of the collection that had already entered in the flowering stage apparently have more developed plant architecture. However, a relationship between these variables should only be established when a larger portion of the plants enters the reproduction phase.

Estimates of the heritability coefficient at the level of family means $\left(\mathrm{h}_{\mathrm{m}}^{2}\right)$ and the coefficient of genetic variation $\left(\mathrm{CV}_{\mathrm{g}}\right)$ per subpopulation are shown in Table 3. The $\mathrm{CV}_{\mathrm{g}}$ values were high for most subpopulations, compared with estimates commonly found in cultivated species. Subpopulations 6 and 9 are exceptions for height and subpopulations 6,8 and 9 for diameter.

Higher $\mathrm{h}_{\mathrm{m}}{ }_{\mathrm{m}}$ values indicate a better condition for selection and higher gains in the following generations. If a breeding program is planned with a restricted number of subpopulations and if selection is carried out in this growth stage, subpopulations 1 , 3, 4, 7 and 10 (subpopulations of the counties of Catalão, Três Ranchos, Cristalina and Senador Canedo, respectively) could be given priority breeding programs.

There was no evident relationship between the genetic variability and the geographic location of the subpopulations (Figure 1). Subpopulation 9, with lowest $\mathrm{CV}_{\mathrm{g}}$ and $\mathrm{h}_{\mathrm{m}}^{2}$ values, is located in an urban area, completely isolated from the others, with exception of subpopulation 10 and with a genetic constitution that was possibly altered by germplasm introductions through human interference (SILVA, 2000; TelLes, 2000). Subpopulation 8, also with lower genetic variability, grows relatively distant from the others. This population consists mainly of trees of small plant architecture, in an apparently recovering Cerrado area, after human interference (SILVA, 1999). The measures of genetic variation $\mathrm{h}_{\mathrm{m}}^{2}$ and $\mathrm{CV}_{\mathrm{g}}$ are not properties of traits only, but depend on the degreed of segregation in the subpopulation as well, on the conditions of the environment in which the trees are evaluated, on the age of the trees, on the experimental design, etc. (VenCOVSKY and BARRIGA, 1992).

One of the poorly studied traits in native species is growth rate. This important trait associated to adaptation tended to show lower heritabilities than plant height and diameter in our study. Nonetheless, the genetic control of this property was evident.

In improvement programs, base populations with adequate means and wide genetic variation are ideal, from which continuous gains with selection could be expected over several generations (RESENDE, 1999). In this case, it is important to consider that subpopulation 7 , in spite of higher estimated gains 
from selection, among as well as within progenies, presented considerably lower mean height and diameter in all years of evaluation, compared with subpopulations 1, 3, 4 and 10. If these traits were therefore target in a future improvement program, or if they presented positive correlation with fruit yield or with other traits related to yield and fruit quality, subpopulation 7 should by no means be considered for selection, unless it presented a better performance in an evaluation for other traits of the breeder's interest.

Morphological traits of cagaita fruits, of the 10 subpopulations of the southeastern region as well as of 13 subpopulations of the northeastern region of the state of Goiás, were studied by SILVA et al. (2001) and Trindade and Chaves (2005), respectively. Both authors observed high genetic variability among and within populations. According to Trindade and Chaves (2005) fruit weight contributed most to the phenotypic divergence among subpopulations, indicating a possibility of selection of superior seed trees for this trait. SiLva et al. (2001) verified the existence of a positive and significant correlation between fruit weight and traits of initial development of the trees, essential characteristics when one aims at the production of more vigorous seedlings. According to this author selection of heavier fruits could therefore result in a shorter time spent on the initial development of the families.

Table 3. Heritability estimates at the progeny mean level $\left(\mathrm{h}^{2}{ }_{\mathrm{m}}\right)$, coefficient of genetic variation $\left(\mathrm{CV}_{\mathrm{g}}\right)$ and the mean

$(\bar{X})$ for the eight variables of ten cagaita (E.dysenterica) subpopulations in the southeast of the state of Goiás

\begin{tabular}{|c|c|c|c|c|c|c|c|c|c|c|c|}
\hline \multirow{2}{*}{\multicolumn{2}{|c|}{ Est. Var. }} & \multicolumn{10}{|c|}{ Subpopulations } \\
\hline & & 1 & 2 & 3 & 4 & 5 & 6 & 7 & 8 & 9 & 10 \\
\hline \multirow{5}{*}{$\bar{X}$} & $\mathrm{H} 1$ & 0.65 & 0.62 & 0.58 & 0.71 & 0.48 & 0.58 & 0.58 & 0.58 & 0.56 & 0.63 \\
\hline & $\mathrm{H} 2$ & 1.01 & 0.99 & 0.89 & 1.09 & 0.83 & 0.94 & 0.98 & 1.01 & 0.94 & 1.00 \\
\hline & H3 & 1.54 & 1.51 & 1.40 & 1.64 & 1.30 & 1.43 & 1.52 & 1.58 & 1.38 & 1.54 \\
\hline & $\mathrm{H} 4$ & 1.75 & 1.67 & 1.63 & 1.79 & 1.47 & 1.63 & 1.70 & 1.77 & 1.50 & 1.75 \\
\hline & $\mathrm{bH}$ & 0.38 & 0.38 & 0.37 & 0.38 & 0.34 & 0.37 & 0.37 & 0.41 & 0.35 & 0.39 \\
\hline \multirow[t]{5}{*}{$\mathrm{h}_{\mathrm{m}}^{2}$} & $\mathrm{H} 1$ & 0.43 & 0.11 & 0.00 & 0.31 & 0.36 & 0.00 & 0.34 & 0.28 & 0.00 & 0.55 \\
\hline & $\mathrm{H} 2$ & 0.50 & 0.42 & 0.28 & 0.45 & 0.46 & 0.04 & 0.55 & 0.37 & 0.00 & 0.44 \\
\hline & H3 & 0.51 & 0.18 & 0.55 & 0.54 & 0.34 & 0.00 & 0.73 & 0.35 & 0.00 & 0.52 \\
\hline & $\mathrm{H} 4$ & 0.58 & 0.20 & 0.34 & 0.52 & 0.40 & 0.02 & 0.71 & 0.40 & 0.00 & 0.58 \\
\hline & $\mathrm{bH}$ & 0.53 & 0.47 & 0.32 & 0.50 & 0.13 & 0.00 & 0.58 & 0.07 & 0.16 & 0.51 \\
\hline \multirow{5}{*}{$\mathrm{CV}_{\mathrm{g}}$} & $\mathrm{H} 1$ & 15.41 & 6.74 & 0.00 & 12.50 & 18.89 & 0.00 & 14.66 & 12.84 & 0.00 & 20.96 \\
\hline & $\mathrm{H} 2$ & 16.31 & 14.99 & 11.55 & 15.17 & 19.90 & 3.56 & 19.58 & 12.96 & 0.00 & 15.38 \\
\hline & H3 & 17.44 & 8.57 & 21.12 & 19.35 & 15.55 & 0.00 & 29.04 & 12.37 & 0.00 & 18.41 \\
\hline & $\mathrm{H} 4$ & 19.27 & 8.90 & 12.86 & 18.55 & 17.06 & 2.46 & 26.92 & 13.24 & 0.00 & 19.75 \\
\hline & $\mathrm{bH}$ & 23.84 & 21.68 & 15.99 & 24.85 & 10.20 & 0.00 & 24.76 & 5.86 & 10.69 & 22.88 \\
\hline \multirow[t]{5}{*}{$\bar{X}$} & D1 & 1.03 & 0.94 & 1.08 & 1.21 & 0.84 & 0.94 & 0.98 & 1.10 & 1.22 & 1.24 \\
\hline & D2 & 2.21 & 2.11 & 1.98 & 2.40 & 1.81 & 2.00 & 1.86 & 2.23 & 2.17 & 2.32 \\
\hline & D3 & 3.12 & 2.86 & 2.90 & 3.21 & 2.90 & 2.80 & 2.84 & 2.98 & 3.20 & 3.32 \\
\hline & D4 & 3.73 & 3.43 & 3.68 & 3.79 & 3.63 & 3.36 & 3.37 & 3.67 & 3.59 & 3.88 \\
\hline & $\mathrm{bD}$ & 0.90 & 0.83 & 0.88 & 0.86 & 0.94 & 0.83 & 0.82 & 0.88 & 0.82 & 0.90 \\
\hline \multirow[t]{5}{*}{$\mathrm{h}_{\mathrm{m}}^{2}$} & D1 & 0.53 & 0.00 & 0.26 & 0.63 & 0.12 & 0.14 & 0.45 & 0.03 & 0.31 & 0.42 \\
\hline & D2 & 0.68 & 0.21 & 0.45 & 0.61 & 0.24 & 0.00 & 0.37 & 0.38 & 0.12 & 0.37 \\
\hline & D3 & 0.50 & 0.28 & 0.57 & 0.51 & 0.47 & 0.11 & 0.54 & 0.14 & 0.17 & 0.41 \\
\hline & D4 & 0.46 & 0.36 & 0.64 & 0.39 & 0.33 & 0.15 & 0.45 & 0.01 & 0.13 & 0.17 \\
\hline & $\mathrm{bD}$ & 0.11 & 0.47 & 0.63 & 0.05 & 0.32 & 0.01 & 0.34 & 0.00 & 0.00 & 0.00 \\
\hline \multirow{5}{*}{$\mathrm{CV}_{\mathrm{g}}$} & D1 & 25.93 & 0.00 & 14.37 & 30.57 & 11.76 & 11.39 & 24.31 & 3.83 & 14.05 & 17.66 \\
\hline & D2 & 26.21 & 10.25 & 18.48 & 23.42 & 13.52 & 0.00 & 17.27 & 14.41 & 6.97 & 13.36 \\
\hline & D3 & 18.13 & 12.81 & 22.87 & 20.26 & 19.61 & 7.26 & 22.19 & 7.71 & 8.03 & 14.59 \\
\hline & D4 & 15.16 & 13.69 & 22.67 & 14.55 & 12.81 & 7.93 & 16.80 & 1.57 & 6.58 & 7.27 \\
\hline & $\mathrm{bD}$ & 6.65 & 19.64 & 25.10 & 4.97 & 12.90 & 2.47 & 14.99 & 0.00 & 0.00 & 0.00 \\
\hline
\end{tabular}

$\mathrm{H}_{1}$ and $\mathrm{D}_{1}$ height and diameter in the $1^{\text {th }}$ year after planting $(1=1,2,3,4)$. bH and bD growth rate of height and diameter. 1, 2 and $3-$ subpopulations of the county of Catalão; 4- Três Ranchos ; 5 and 6- Campo Alegre de Goiás; 7- Cristalina; 8- Luziânia; 9 - Goiânia and 10Senador Canedo. 
The germplasm collection of Eugenia dysenterica of the Escola de Agronomia e Engenharia de Alimentos of the Universidade Federal de Goiás contains sufficient genetic variability for the development of improved populations. In future studies of improvement and conservation of the species and above all in tests of origin and progenies, the traits earliness, yield and fruit quality in cagaita trees should be considered, together with the indicator traits of vigor.

This is condition to form an orchard of improved seed production. The base population for selection should be chosen with a view to genetic improvement in the long term, that is, by the continuous and progressive increase of the favorable allele frequencies, by means of several selection cycles, mainly with the subpopulations under study showing large genetic variability to be exploited. Promising gains can thus be obtained over several selection cycles (RESENDE, 1999). The greatest difficulty of an improvement program of tree and perennial species, such as the present, is the long time required to establish the recombination of the selected plants. In this case TRINDADE (2001) suggests an association of long-term selection programs with ex situ conservation programs, where families are planted in an experimental scheme, as done here.

\section{CONCLUSIONS}

1. The natural Eugenia dysenterica subpopulations, represented in the living germplasm collection of the Escola de Agronomia e Engenharia de Alimentos of the UFG, present high levels of genetic variation for diameter and height in juvenile trees and for the respective growth rates.

2. The greatest part of the existing genetic variation is contained within subpopulations. This indicates that in pre-breeding program for growth traits selection is possible among and within families, disregarding selection among subpopulations.

3. If a program cannot accommodate several subpopulations those from the counties of Catalão (subpopulations 1 and 3), Três Ranchos (subpopulation 4), Cristalina (subpopulation 7) and Senador Canedo (subpopulation 10) should be chosen in future programs.

4. In view of the expected progress, the collection could be transformed into a seedling seed orchard, without rouging, where seeds are collected from the phenotypically superior trees of the selected progenies.

\section{ACKNOWLEDGEMENTS}

Authors are also grateful for the support given by CNPq. CAPES supported one of the authors with a scholarship throughout the course.

\section{REFERENCES}

CHAVES, J.L.; TELLES, M.P.C. Cagaita. In: VIEIRA, R.F.; COSTA, T.S.A.; SILVA, D.B.; FERREIRA, F.R.; SANO, S.M. Frutas nativas da região centro-oeste do Brasil. Brasília: EMBRAPA-Cenargen, 2006. p.20-134.

CORRÊA, M.P. Dicionário das plantas úteis do Brasil. Rio de Janeiro: Imprensa Nacional, 1984. p.1926-1978.

MORAES, M.L.T. Variabilidade genética por isoenzimas e caracteres quantitativos em duas populações naturais de aroeira (Myracroduon urundeuva F.F. \& M.F. allemãoAnarcadiaceae (Syn: Astronium urundeuva (Fr. Allemão) Engler. 1992. 139f. Tese - Escola Superior de Agricultura Luiz de Queiroz- Universidade de São Paulo, Piracicaba.

PROENÇA, C.E.B.; GIBBS, P.E. Reproductive biology of eight sympatric Myrtaceae from Central Brazil. New Phytologist, v.126, p.343-354, 1994.

RESENDE, M.D.V. Melhoramento de essências florestais. In: BORÉM, A. Melhoramento de espécies cultivadas. Viçosa: Editora UFV, 1999. p.589-647.

RESENDE, M.D.V.; VENCOVSKY, R.;FERNANDES, J.S.C. Selection and genetic in populations of Eucalyptus with mixed mating systems. In: CONFERENCE ON EUCALYPT PLANTATIONS: IMPROVING FIBRE YIELD AND QUALITY. Hobart: IUFRO, 1995. p.191-193.

SILVA, R.S.M. Caracterização de sub-populações de cagaita (Eugenia dysenterica DC.) da região sudeste do Estado de Goiás. 1999. 107f. Dissertação (Mestrado em Agronomia) Universidade Federal de Goiás-UFG, Goiânia.

SILVA, R.S.M.; CHAVES, L.J. and NAVES, R.V. Caracterização de frutos e árvores de cagaita (Eugenia dysenterica DC.) no sudeste do Estado de Goiás Brasil. Revista Brasileira de Fruticultura, v.23, p.330-334, 2001.

TELLES, M.P.C. Diversidade genética e estrutura genética populacional de cagaiteira (Eugenia dysenterica DC.) do sudeste de Goiás. 2000. 129f. Dissertação (Mestrado em Agronomia) - Universidade Federal de Goiás-UFG, Goiânia.

TELLES, M.P.C.; DINIZ FILHO, J.A.F.; COELHO, A.S.G. and CHAVES, L.J. Autocorrelação espacial das freqüências alélicas em subpopulações de cagaiteira (Eugenia dysenterica DC. Myrtaceae) no sudeste de Goiás. Revista Brasileira de Botânica, v.24, n.2, p.145-154, 2001a.

TELLES, M.P.C.;SILVA, R.S.M.; CHAVES, L.J.; COELHO, A.S.G. and DINIZ FILHO, A.F. Divergência entre subpopulações de cagaiteira (Eugenia dysenterica) em resposta a padrões edáficos e distribuição espacial. Pesquisa Agropecuária Brasileira, v.36, n.11, p.1387-1394, 2001b. 
TELLES, M.P.C.; COELHO, A.S.G.; CHAVES, L.J.; DINIZFILHO, J.A.F.; VALVA, F.D. Genetic diversity and population structure of Eugenia dysenterica DC. ("cagaiteira"-Myrtaceae) in central Brazil: spatial analysis and implication for conservation and management. Conservation Genetics, v.4, p.685-695, 2003.

TRINDADE, M.G. Estrutura genética de subpopulações naturais de cagaiteira (Eugenia dysenterica DC) do nordeste de Goiás. 2001. 99f. Dissertação (Mestrado em Agronomia), Escola de Agronomia - Universidade Federal de Goiás - UFG, Goiânia.

TRINDADE, M.G.; CHAVES, L.J. Genetic structure of natural Eugenia dysenterica DC (Myrtaceae) populations in northeastern Goiás, Brazil, acessed by morphological traits and RAPD markers. Genetics and Molecular Biology, v.28, p.407-413, 2005.

VENCOVSKY, R.; BARRIGA, P. Genética biométrica no fitomelhoramento. Ribeirão Preto: Sociedade Brasileira de Genética, 1992. 486p.

VENCOVSKY, R.; PEREIRA, M.B.; CRISÓSTOMO, J.R.; FERREIRA, M.A.J.F. Genética e melhoramento de subpopulações mistas. In.: NASS, L.L.; VALOIS, A.C.C.; MELO, I.S.; VALADRES-INGLIS, M.C. Recursos genéticos e melhoramento de plantas. Rondonópolis: Editora FundaçãoMT, 2001, p.231-281.

ZUCCHI, M.I. Análise da estrutura genética de Eugênia dysenterica DC utilizando marcadores RAPD e SSR. 2002. 130f. Tese (Doutorado em Genética e Melhoramento de Plantas) - Escola Superior Luiz de Queiroz (ESALQ), Universidade de São Paulo (USP), Piracicaba.

ZUCCHI, M.I.; BRONDANI, R.V.; PINHEIRO, J.B.; CHAVES, L.J.; COELHO, A.G.S. and VENCOVSKY, R. Genetic structure and gene flow in Eugenia dysenterica DC in Brazilian Cerrado utilizing SSR markers. Genetics and Molecular Biology, v.26, p.449-457, 2003.

ZUCCHI, M.I.; PINHEIRO, J.B.; CHAVES, L.J.; COELHO, A.S.G.; COUTO, M.A.; MORAIS, L.K. and VENCOVSKY, R. Genetic structure and gene flow of Eugenia dysenterica natural populations. Pesquisa Agropecuária Brasileira, v.40, n.10, p. 975-980, 2005. 